\title{
原種オーミ二豚の血液蛋白質型からみた遺伝子構成
}

\author{
近 江 俊 徳 ${ }^{2}$ 坂 上 正 行 $^{1}$. 田 中 一 栄 ${ }^{1}$ \\ ' 東京農業大学家畜育種学研究室、東京都 156 \\ ${ }^{2}$ 現 自治医科大学法学人類遺伝学教室、栃木県 $329-04$
}

\section{Gene constitution of original stock Ohmini pigs analysed by blood protein polymorphisms}

\author{
Toshinori Ohmi ${ }^{2}$, Masayuki Sakagami ${ }^{1}$, \\ and Kazue Tanaka ${ }^{1}$ \\ ${ }^{1}$ Laboratory of Animal Breeding, Tokyo university \\ of Agriculture Tokyo 156 \\ ${ }^{2}$ Present; Department of leagal medicine and human genetics, \\ Jichi medical school, Tochigi 329-04
}

ミニブタは解剖学的、生理学的特徵において人と多く の類似点を持ち、家畜ブ夕に比べ扱いやすいことから医 学および生物学において、実験用動物として利用されて いる。ミニブタの育種を最初に報告したのは、1949年ミ ネソタ大学の winter らである。以来、アメリカのミネ ソタをはじめ、ホメール、ピッツマン・ムーア、ハンフォ ード、ユカタン、ドイッのゲッチンゲン、台湾のリーソ ンなどのミニブタが作出された。今回、我々が検討した ミニブタは、(株日本家畜研究所の近江によって作出され、 1942年、1949年、1960年の 3 回にわたり中国東北部より 導入された荷包猪を基礎に改良された原種オーミニ（以 下原種）である。現在、実験用動物として利用されてい るのは、原種および原種と欧米改良種を交配したオーミ 二系である。原種およびオーミニ系を含めた集団の血液 系遺伝標識はすでに大石と富田（1976）によって調査さ れている。しかし、導入時以降閉鎖的に飼養されて来た 原種集団の血液系遺伝標識については明らかにされてい ない。そこで、我々は現在飼養されている原種集団につ いて、これまで明らかにされていない血球酵素型を加え た血液蛋白質型を調査し大石と富田の調査した原種の成 績と比較検討した。

\section{材料および方法}

調查対象のオーミニは、栃木県の(侏)日本家畜研究所で 維持されている原種31頭であり、血液サンプルは耳静脈
より採血を行い、血漿と血球に遠心分離後、 $-20^{\circ} \mathrm{C}$ に凍 結保存したものを実験に供した。本研究において、分析 された遺伝子座および電気泳動法は以下の通りである。 Serum prortein or enzymes: prealbumin $(\mathrm{Pa})$, transferrin ( $\mathrm{Tf})$, ceruloplasmin $(\mathrm{Cp})$, amylase$1(\mathrm{Am}-1)$, and hemopexin ( $\mathrm{Hp})$, Ohishi et al., 1976; Erythrocyte protein or enzymes: NADHdiaphorase- I (Dia-I) and NADH-diaphoraseII (Dia- II ), Tucker \& Clowley, 1978; esterase (CEs), Kloster et al., 1970; esterase-D (Es-D), Tanaka et al., 1979; glyoxalase- I (GLO- I ), Korpe et al., 1975; hemoglobin $\alpha$-chain $(\mathrm{Hb}-\alpha)$ and hemoglobin $\beta$-chain $(\mathrm{Hb}-\beta)$, Chernoff \& Pettiti, 1964; adenylate kinase (AK), lactate dehydrogenase (LDH), and malate dehydrogenase $(\mathrm{MDH})$, Shaw \& Prasad, 1970; phosphoglucomutase (PGM), 6-phoshogluconate dehydrogenase (6PGD), and phosphohexose isomerase (PHI), Ohishi \& Abe, 1979; tetrazolium oxidase (TO), Baur \& Schorr, 1969.

これらの血液蛋白質型から、変異の検出された遺伝子 座に拈ける、対立遺伝子の頻度を算出した。また、大石 と富田の調查した原種の結果との比較は、共通の遺伝子 座について行った。 
Table 1. Genotypes and gene frequencies on two polymorphic loci of blood protein in original stoc ohmini pigs

\begin{tabular}{cccccccccc}
\hline Locus & $\mathrm{N}$ & \multicolumn{4}{c}{ Genotype } & \multicolumn{3}{c}{ Gene frequency } \\
\hline & & & $\mathrm{AA}$ & $\mathrm{AB}$ & $\mathrm{BB}$ & & $A m^{A}$ & $A m^{B}$ \\
Am- I & 31 & & 13 & 15 & 3 & & 0.061 & 0.339 \\
\hline & & $1-2$ & $1-3$ & $2-2$ & $2-3$ & $3-3$ & $\mathrm{Hp}^{1}$ & $H p^{2}$ & $H p^{3}$ \\
$\mathrm{Hp}$ & 31 & 1 & 1 & 6 & 14 & 9 & 0.032 & 0.436 & 0.532 \\
\hline
\end{tabular}

\section{結果および考察}

オーミニ豚原種集団について19種類の血液蛋白質型を 調査したところ Hp、Am- I の 2 座位に多型を認めた。 Table 1 にこれらの座位における表現型変異と遺伝子頻 度を示した。また、その他の座位すなわち $\mathrm{Tf} 、 \mathrm{Cp}$ 、 Dia- I、 Dia- I、CEs 、EsD 、 GLO-I 、Hb- $\alpha 、$ Hb- $\beta$ 、 AK、LDH、PGM、6PGD、PHI、TOについてはす ベてMonomorphicであった。その中で対立遺伝子が 明らかにされている $\mathrm{Tf} 、 \mathrm{~Pa} 、 \mathrm{Cp} 、 \mathrm{PHI} 、 6 \mathrm{PGD} 、 \mathrm{PGM}$ 、 $\mathrm{EsD}$ 座位では、それぞれ $T f^{B} 、 P a^{A} 、 C p^{B} 、 P H I^{B} 、$ $6 P G D^{A} 、 P G M^{B} 、 E s D^{A}$ 遺伝子に固定されていた。こ れらの結果は、原種集団がかなり均質度の高い集団であ り、長い間サイズの小さい閉鎖集団として維持されてき たことを反映しているものと思われた。

さらに、今回調査した原種集団と1976年調査の原種集 団とを比較するため、大石と富田の調査した原種および オーミニ系集団の中より、原種のみのデー夕を抽出し共 通の血清蛋白 5 座位について検討した。また、両集団の 遺伝子頻度をTable 2 に示した。遺伝子頻度に差がみ られた座位は $\mathrm{Hp} 、 \mathrm{Am}-\mathrm{I} 、 \mathrm{Cp}$ であった。すなわち、

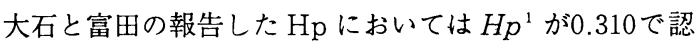
められていたが、今回の調査では $H p^{1}$ は全く検出され ずに新たに $H p^{3}$ が0.532の頻度で認められた。Am- I においては $A m^{A} 、 A m^{B}$ 各遺伝子が共に0.500の頻度で 認められていたが、今回の調査では $A m^{A}$ が0.661、Am ${ }^{B}$ が0.339 と若干 $A m^{A}$ 遺伝子の增加を認めた。そして $C p$ においては $C p^{\text {ohmi }}$ が0.053で認められていたが、今回の 調查では $C p^{b}$ に固定されていた。以上のように 3 座位 の遺伝子頻度に若干差が認められたことから、血清蛋白 5 座位だけでは即断することはできないが、主要な遺伝 子頻度に大きな変化は認められず、オーミ二豚原種集団 の遺伝子構成は、ホモ化の傾向にあるものと考えられた。

\section{要 約}

侏日本家畜研究所で維持されている原種オーミ二豚 31 頭について、これまでに明らかにされていない血球酵素
型11座位を加えた血液蛋白質型19座位を調査し、その遺 伝子構造を明らかにすると共に、これまで報告されてい る成績と比較検討した。

1）調査した血液蛋白質型19種類の遺伝子座のなかで Hp、Am-Iの 2 座位に多型を認めた。しかし、その他 の座位はすべて Monomorphicであった。その中でこ れまでに対立遺伝子が明らかにされている座位において は、それぞれ $T f^{B} 、 P a^{A} 、 C p^{B} 、 P H I^{B} 、 6 P G D^{A} 、 P G M^{B} 、$ および $E s D^{A}$ 遺伝子に固定されていた。

2）血清蛋白質 5 座位の遺伝子頻度について、1976年大

Table 2 Gene frequencies of five serum protein polymorphisms in original stock Ohmini pigs

\begin{tabular}{ccll}
\hline & & \multicolumn{2}{c}{ Gene frequency } \\
\cline { 3 - 4 } Locus & Allele & 1976 & 1988 \\
\hline $\mathrm{Tf}$ & $T f^{A}$ & 0 & 0 \\
& $T f^{B}$ & 1,000 & 1,000 \\
& $T f^{c}$ & 0 & 0 \\
\hline $\mathrm{Pa}$ & $P a^{A}$ & 1,000 & 1,000 \\
& $P a^{B}$ & 0 & 0 \\
\hline $\mathrm{Hp}$ & $H p^{1 F}$ & 0.316 & 0 \\
& $H p^{1}$ & 0 & 0.032 \\
& $H p^{2}$ & 0.474 & 0.436 \\
& $H p^{3}$ & 0.210 & 0.532 \\
\hline \multirow{2}{*}{$\mathrm{Cp}$} & $C p^{B}$ & 0.947 & 1,000 \\
& $C p^{\text {ohmi }}$ & 0.053 & 0 \\
\hline $\mathrm{Am}$ & $A m^{A}$ & 0.500 & 0.661 \\
& $A m^{B}$ & 0.500 & 0.339 \\
\hline
\end{tabular}


石と富田の調查した成績と比較したところ、遺伝子頻度 に差がみられたのは Hp、Am- I、Cpであった。しか し、オーミ二豚の原種集団に扔ける遺伝子構造に大きな 変化は認められず、閉鎖集団として維持されてきたこと が反映された結果となった。

\section{謝辞}

本調査研究の実施にあたり、採血のご協力を賜わった (株)日本家畜研究所近江俊文氏、ならびに東京農業大学家 畜育種学研究室、市原裕子さん、林智子さん、小堀一弥 君、山本敬一君に対して哀心より謝意を表する。

\section{文献}

Baur, E.W. \& R. T. Schorr, 1969 Science., 166: 1524-1525.

Bustad, L. K. \& R. O. McClellan, 1968 Lab. Anim, 18: 280.

Chernoff, A. Z. \& N. M. Pettiti, 1964 Blood., 24: 750-756.

England, D. C., L. M. Winters \& L. E. Carpenter,
1954 Growth., 18: 207.

Kormpe, J., S. Bissbort, S. Gussmann \& H. Ritter, 1975 Humangenetik., 27: 141-167.

Kroster, G., B. Larsen \& P. C. Nielsen, 1970 Acta. Vet. Scand., 11: 318-321.

大石孝雄・阿部恒夫 ·茂木一重、1970 日畜会報、41： 364-371.

大石孝雄・阿部恒夫、1979 畜試研報、35:9-18

Oishi, T. \& T. Tomita, 1976 Anim. Blood Grps.

Biochem. Genet., 7: 27-32.

Panepinto, L. M. \& R.W. Phillips, 1986 Lab. Anim. 15: 21-27.

Shaw, C. R. \& R. Prasad, 1970 Biochem. Genet., 4: 297-320.

Sou, E., 1984 Anim. Exp. Lab. Anim., 1: 3.

Tanaka, K., Y. Kurosawa, K. Kurokawa \& T. Oishi, 1979 Anim. Blood Grps. Biochem. Genet., 11: 193-197.

Tucker, E. M. \& C. Crowley, 1978 Anim. Blood Grps. Biochem. Genet., 9: 161-167. 